\title{
Corporate Rescue : Key Concept dalam Kepailitan Korporasi
}

\author{
Asra \\ Hakim Pengadilan Tinggi Tanjung Karang \\ Jl. Cut Meutia No. 40 Bandar Lampung \\ asra@gmail.com
}

\begin{abstract}
The problems discussed in this research are: first, how is the relationship between liquidation concept and the bankruptcy of solvable and viable (prospective) companies in Indonesia? Second, how is the attitude of the Supreme Court towards the bankruptcy of solvable companies in Indonesia? Third, how is the ideal concept of Indonesia's corporate bankruptcy law in the future? This was a normative research. This research concludes, first, there is a relationship between the bankruptcy of solvable and viable (prospective) companies in the Commercial Court and liquidation concept implemented in Bankruptcy Law. Second, related to the bankruptcy of solvent companies in the Commercial Court, the Supreme Court calls off the adjudication of the Commercial Court according to several considerations, including the fact that the companies are still prospective and deserve an opportunity to continue their business and the bankruptcy proposal cannot be proven in a simple way. Third, the ideal concepts of Indonesia's bankruptcy law in the future are (i) Separating the bankruptcy of corporate and individual. (ii) Insolvent becomes a standard of corporate bankruptcy. (iii) Implementing the principles of business continuity which becomes a concept of corporate rescue in the norm of Corporate Bankruptcy Law or Limited Liability Company Acts. (iv) There is a stricter regulation of revocation of bankruptcy of companies which no longer own their assets.
\end{abstract}

Key word: Bankruptcy, corporate, solvable, viable

\begin{abstract}
Abstrak
Permasalahan-permasalahan yang menarik dikaji dalam penelitian ini: pertama, bagaimanakah hubungan konsep likuidasi dengan pailitnya perusahaan-perusahaan solvable dan viable (prospektif) di Indonesia? Kedua, bagaimanakah sikap Mahkamah Agung terhadap pailitnya perusahaanperusahaan solvable di Indonesia? Ketiga, bagaimanakah konsep ideal hukum kepailitan korporasi Indonesia di masa depan? Penelitian ini merupakan penelitian normatif. Penelitian ini menyimpulkan, pertama, pailitnya perusahaan-perusahaan yang masih solvable dan viable (prospektif) di Pengadilan Niaga ada hubungannya dengan konsep likuidasi yang diterapkan di dalam Undang-Undang Kepailitan. Kedua, pailitnya perusahaan-perusahaan solvent di Pengadilan Niaga, disikapi oleh Mahkamah Agung dengan membatalkan putusan hakim Pengadilan Niaga berdasarkan berbagai pertimbangan, diantaranya perusahaan tersebut masih prospektif dan masih harus diberi kesempatan untuk melanjutkan bisnis perusahaannya dan permohonan pailit tersebut tidak dapat dibuktikan secara sederhana. Ketiga, konsep ideal hukum kepailitan Indonesia ke depan (i) Memisahkan kepailitan korporasi dari kepailitan perseorangan. (ii) Insolvent menjadi ukuran untuk kepailitan korporasi. (iii) Menerapkan asas kelangsungan usaha yang merupakan konsep corporate rescue dalam norma Undang-Undang Kepailitan Korporasi atau Undang-Undang Perseroan Terbatas. (iv) Adanya aturan yang lebih tegas terhadap pencabutan kepailitan perusahaan yang sudah tidak lagi mempunyai asetasetnya.
\end{abstract}

Key word: Kepailitan, korporasi, solvable, viable 


\section{Pendahuluan}

Pailitnya perusahaan-perusahan yang masih solvent dan viable (prospektif) di pengadilan niaga ada hubungannya dengan konsep dan prinsip hukum yang diterapkan dalam suatu peraturan perundang-undangan, seperti pailitnya PT Moderndland Reality, PT Asuransi Jiwa Manulife Indonesia, PT Televisi Pendidikan Indonesia, PT Telkom dan lain-lainnya. Hukum kepailitan bukan lagi merupakan penerapan prinsip commercial exit from financial distress, ${ }^{1}$ tetapi merupakan alat yang dapat memusnahkan perusahaan-perusahaan yang solvent. Sedangkan persoalan konsep berhubungan dengan konsep yang diterapkan dalam Undang-Undang Kepailitan. Undang-Undang No. 4 Tahun 1998 sebagaimana yang telah diubah dengan Undang-Undang No. 37 Tahun 2004 yang menerapkan konsep likuidasi yang dibangun berdasarkan teori Jackson's creditor bargain, bahkan melebihi konsep likuidasi ini, dengan menghilangkan syarat insolvent didalamnya. ${ }^{2}$ Untuk melunasi utang-utangnya aset-aset perseroan harus dilikuidasi. ${ }^{3}$ Sekarang, konsep ini di negara lain sudah mulai ditinggalkan, yang diterapkan adalah konsep corporate rescue. Konsep ini dianut Undang-Undang Kepailitan sebagai asas kelangsungan usaha, tetapi tidak diimplementasikan penerapan dalam pasal-pasalnya, padahal asas inilah yang merupakan corporate rescue yang menjadi key concept dalam kepailitan korporasi di negara maju saat ini.

Hukum kepailitan Indonesia ini yang pada mulanya merupakan warisan dari zaman Belanda, yaitu berasal dari Faillissement Verordening Staatsblaad Tahun 1905 No. 217 Juncto Staatsblad Tahun 1906 No. 348 (FV), yang menganut sistem hukum Eropa Kontinental, Staatsblad Tahun 1905 No. 217 Juncto Staatsblad Tahun

${ }^{1}$ Salah satu prinsip pokok hukum kepailitan dimana hukum kepailitan berfungsi sebagai jalan keluar dari masalah keuangan yang dialami suatu perusahaan. Lihat Hadi Subhan, Hukum Kepailitan, Prinsip,Norma dan Praketek di Peradilan, Kencana Prenada Media Group, Jakarta, 2008, hlm. 64. 2000, hlm. 17.

${ }^{2}$ Jerry Hoff, UU Kepailitan di Indonesia, (Indonesia Bankruptcy Law), Terjemahan Kartini Mulyadi, Jakarta,

3 Penyelesaian pembayaran utang utang dengan cara melikuidasi aset-aset debitor yang dilakukan dengan menggunakan Undang-Undang No. 4 Tahun 1998 ini tidaklah efektif. Ada hasil penelitian yang menyatakan bahwa setelah tiga tahun Undang-Undang Kepailitan ini dioperasionalkan, seorang kurator menyebutkan bahwa nilai pemulihan utang yang umum dicapai dalam proses kepailitan hanya rata-rata sebesar $11,6 \%$ dari nilai utang pokok. Nilai ini jelas tidak menunjukkan hasil yang memuaskan bagi kreditor, sehingga tidak sedikit kreditor yang kaget dan kecewa akan hasil proses kepailitan. Belum lagi adanya indikasi-indikasi penyimpangan para pemain dalam perkara kepailitan, misalnya kasus kreditor fiktif dan lainnya.Kurangnya kemampuan Undang-Undang Kepailitan untuk melindungi harta pailit dari jarahan tangan nakal pihak yang tidak bertanggung jawab, padahal sisi inilah yang paling vital dari seluruh proses kepailitan. Lihatfile://C:/Program\%20File/DatabaseKepailitan/Resume.htm, akses 31 Maret 2014. 
1906 No. 348 (FV), yang kemudian dilakukan revisi dengan Undang-Undang No. 4 Tahun 1998 Juncto Peraturan Pemerintah Pengganti Undang-Undang (PERPU) No. 1 Tahun 1998,4 yang sekarang secara total telah diubah dengan UndangUndang No. 37 Tahun 2004. Undang-Undang Kepailitan ini dibutuhkan sebagai akibat krisis ekonomi pada Tahun 1997 dengan asumsi bahwa akan banyak perusahaan yang tidak akan membayar utang-utang sebagai akibat krisis ekonomi Tahun 1997, maka diperlukan lembaga hukum kepailitan yang dapat secara cepat menyelesaikan utang-utangnya. ${ }^{5}$

Jika diperhatikan sistimatika Undang-Undang Kepailitan No. 4 Tahun 1998 sebagaimana yang telah diubah dengan Undang-Undang No. 37 Tahun 2004 terdapat ketentuan untuk melikuidasi aset-aset debitor dan ketentuan mengenai PKPU (Permohonan Penundaan Pembayaran Utang). ${ }^{6}$ PKPU bukanlah merupakan opsi yang diutamakan, pernyataan pailit dengan tujuan untuk melikuidasi aset debitor adalah merupakan tujuan utama. Untuk itu dibuatlah syarat yang memudahkan debitor dinyatakan pailit, hanya adanya dua kreditor, adanya utang yang telah jatuh tempo dan dapat ditagih, dan debitor tidak membayar utangnya (not paying debts), ${ }^{7}$ debitor harus dinyatakan pailit. Di samping itu, Undang-Undang Kepailitan juga tidak membedakan kepailitan korporasi dengan perseorangan, maka akan lebih mudah untuk menyatakan debitor perusahaan dalam keadaan pailit, yang akan dilanjutkan melikudasi aset perusahaan tersebut.

Menurut hukum kepailitan korporasi, perusahaan-perusahaan yang insolvent dinyatakan pailit dan aset-asetnya dilikuidasi dan yang dinyatakan pailit bukan perusahaan yang solvent. Konsep inipun sudah mulai dtinggalkan, atau

${ }^{4}$ Jerry Hoff, Op. Cit., hlm. 17.

${ }^{5}$ Ibid.

${ }^{6} \mathrm{PKPU}$ mungkin dapat merupakan wadah pelaksanaan asas kelangsungan usaha jika memberikan kesempatan untuk itu, tetapi PKPU selama ini hanya merupakan pemberian kesempatan kepada debitor agar tidak dipailitkan. PKPU bukanlah upaya hukum yang sama tetapi mirip dengan konsep corporate rescue, atau asas kelangsungan usaha.

${ }^{7}$ Jerry Hoff, Loc. Cit. Tidak membayar utang (not paying debts) menjadi ukuran ketidak mampuan dalam Undang-Undang No. 37 Tahun 2004. Ricardo Simanjuntak, Hukum Kontrak, Tehnik Perancangan Kontrak Bisnis, Kontan Publishing, Jakarta, 2006, hlm. 293. Pasal 1 ayat (1) Undang-Undang No. 4 Tahun 1998 merupakan standar dari keadaan tak mampu membayar dan lebih mudah diterapkan. Konsep ini betentangan dengan pengertian insolvent dalam Pasal $47 \mathrm{KUH}$. Dagang: jika perseroan menderita kerugian sebesar tujuh puluh lima persen, maka perseroan tersebut demi hukum bubar. Jadi, perseroan yang dilikuidasi adalah perseroan yang menederita kerugian yang siknifikan, bukan karena tidak membayar utang. 
setidak-tidaknya hanya merupakan ultimun remidium dalam penyelesaian utangutang, korporasi yang insolvent tidak lagi dipailitkan dan likudasi aset-asetnya. Konsep yang menjadi model baru (recent trends) dalam hukum kepailitan korporasi adalah konsep corporate rescue, yang mengakibatkan hukum kepailitan di Asia termasuk di Indonesia out of date, atau ketinggalan zaman menurut versi Asian Development Bank (ADB). Untuk mengikuti perkembangan ini, Menteri Hukum dan Perundang-undangan dan HAM pernah mengajukan RUU restrukturisasi utang dan rehabilitasi perusahaan yang menyerupai Chapter 11 U.S. Bankruptcy Code. ${ }^{8}$

Perkembangan baru ini seolah-olah juga mengilhami kreditor di Indonesia dimana kreditor lebih memilih permohonan PKPU terhadap debitor pailit, seperti dalam permohonan PKPU PT Bank Mandiri Tbk v. PT Berlian Laju Tanker Tbk; PT Asuransi Central Asia v. PT Arpeni Pratama Ocean Line Tbk; PT Pertama Hulu Energy Raja Tempirai dan PT Golden Spike Energy Indonesia v. PT Putra Sejati Indomakmur, namun masih terdapat kemungkinan penyalahgunaan penggunaan PKPU dimana jika PKPU berakhir debitor langsung dinyatakan pailit. Namun jauh sebelumnya, konsep baru dalam hukum kepailitan korporasi ini pernah diterapkan dalam putusan Mahkamah Agung RI No. 024 PK/N/1999 dalam perkara kepailitan antara PT Citra Jimbaran Indah Hotel v. Ssangyong Engineering $\mathcal{E}$ Construction Co. Ltd., Mahkamah Agung RI telah mengabulkan permohonan PK dalam perkara kepailitan ini karena perusahaan debitor masih dalam keadaan prospektif (viable), perusahaan debitor masih perlu diberikan kesempatannya untuk menjalankan bisnisnya sehingga debitor masih berpotensi untuk dapat melunasi utang-utangnya. Kepailitan dengan cara melikuidasi perusahaan debitor dipandang tidak ada manfaatnya. Putusan PK Mahkamah Agung berada dalam konsep corporate rescue dan merupakan terobosan hukum (legal break through) terhadap teks Undang-Undang No. 4 Tahun 1998,9 atau merupakan suatu penemuan hukum (rechtsvervinding) dalam penerapan hukum di Indonesia.

${ }^{8}$ Sutan Remy Sjahdeini, "Recent Development on Indonesia's Bankruptcy Law," Paper yang disampaikan pada The General Meeting of ALA on 26 - 28 May 2003 di Shangri-La Hotel, Singapore, hlm. 23 dan 24.

9Secara normatif, perusahaan-perusahaan tersebut memang harus dipailitkan, tetapi Mahkamah Agung meganulir putusan pengadilan niaga, Mahkamah Agung menerapkan asas kelangsungan usaha dalam putusannya. 
Perkembangan baru ini juga diadopsi oleh Forum for Asia Insolvency Reform (FAIR) yang dilaksanakan pada 27 - 28 April 2006 di Beijing, China, dengan tema Creditor Participation in Insolvency Proceeding, menyebutkan perlunya penerapan konsep corporate rescue dalam hukum kepailitan korporasi di masing-masing negara. Hal ini dilakukan karena pada saat ini hukum kepailitan di banyak negara masih didasari oleh tradisi, budaya dan situasi lokal suatu negara. ${ }^{10} \mathrm{Di}$ samping itu, menurut Asian Development Bank $(A D B)$, ketika terjadi krisis ekonomi pada akhir 1990an, ternyata hukum kepailitan di negara-negara Asia sudah ketinggalan zaman dan tidak sesuai lagi dengan kebutuhan hukum bisnis modern. Untuk mengurangi kesenjangan itu, negara-negara Asia dapat mengadopsi dengan melakukan studi perbandingan hukum, terutama terhadap hukum kepailitan korporasi (corporate insolvency law) di negara-negara common law.

\section{Rumusan Masalah}

Berdasarkan uraian tersebut di atas, permasalahan-permasalahan dalam penelitian ini sebagai berikut: pertama, bagaimanakah hubungan konsep likuidasi dengan pailitnya perusahaan-perusahaan solvable dan viable (prospektif) di Indonesia? Kedua, bagaimanakah sikap Mahkamah Agung terhadap pailitnya perusahaan-perusahaan solvable di Indonesia? Ketiga, bagaimanakah konsep ideal hukum kepailitan korporasi Indonesia di masa depan?

\section{Tujuan Penelitian}

Penelitian ini bertujuan untuk menganalisis: pertama, hubungan konsep likuidasi dengan pailitnya perusahaan-perusahaan solvable dan viable (prospektif) di Indonesia. Kedua, mengetahui sikap Mahkamah Agung terhadap pailitnya perusahaan-perusahaan solvable di Indonesia. Ketiga, menemukan konsep ideal hukum kepailitan korporasi Indonesia di masa depan.

${ }^{10}$ Roman Tomansic, "Creditor Participation in Insolvency Proceedings,"Work Paper, OECD, Paris, 


\section{Metode Penelitian}

Penelitian ini merupakan penelitian hukum normatif yang menggunakan data sekunder yang terdiri dari bahan hukum primer, sekunder dan tersier. Semua bahan hukum yang diperoleh dalam penelitian akan dikumpulkan, dikelompokkan sesuai variabel masing-masing, untuk selanjutnya dianalisis secara kualitatif. dengan menggunakan beberapa pendekatan. Beberapa pendekatan yang digunakan dalam penelitian ini adalah pendekatan perundangundangan (statute approach), pendekatan kasus, dan pendekatan konsep (conceptual approach). Hasil dari penelitian ini akan disajikan dalam bentuk deskriptif analitis.

\section{Hasil Penelitian dan Pembahasan}

Pailitnya perusahaan-perusahaan solvable dan viable (Prospektif) ada hubungannya dengan konsep yang diterapkan dalam UU Kepailitan Indonesia

Dilihat dari latar belakang lahirnya Undang-Undang No. 37 Tahun 2004, undang-undang ini memang dikonsepsikan berfungsi sebagai debt collection dengan semangat untuk melikuidasi aset-aset debitor sebagai bentuk penyelesaian utang-piutang akibat krisis ekonomi pasca 1997. Krisis ekonomi yang terjadi pada akhir 1997 dan terus berlanjut pada tahun-tahun sesudahnya telah menggoncang negara-negara di seluruh kawasan Asia, yang berakibat pada pula terhadap persoalan nilai tukar mata uang rupiah yang mengalami fluktuasi yang sangat tajam dimana nilai rupiah pada mulanya Rp. 2.400,00 per satu US dollarnya menjadi Rp. 14.000,00 per satu US dollar. Utang-utang swasta dan pemerintah jumlahnya menjadi membengkak berlipat kali dan diperkirakan akan banyak perusahaan yang akan mengalami kesulitan likuiditas untuk pembayaran utang-utangnya, dan keadaan pailit pun mungkin tidak dapat dihindari, ${ }^{11}$ namun persolan ini harus diselesaikan.

${ }^{11}$ Mahkamah Agung, Kumpulan Putusan Perkara Kepailitan dalam Putusan Kasasi dan PK, 2000, hlm. 1. Lihat juga Jerry Hoff, Undang-undang Kepailitan di Indonesia, Tatanunsa, Jakarta, Indonesia, 2000, hlm. 3,4,5; dan Majalah Hukum Forum, 22 November 2002 No. 34, hlm. 22-23. 
Oleh karena besarnya peran dan kebutuhan penyelesaian utang, baik swasta maupun pemerintah, maka upaya yang dinilai sangat mendesak dan diwujudkan, maka perlu untuk menghadirkan perangkat hukum yang dapat diterima pihak-pihak yang terkait dengan penyelesaian utang-piutang tersebut, dengan beberapa asumsi. ${ }^{12}$ Pertama, adalah bahwa gejolak di pasar uang dapat dikendalikan, apabila perspektif penyelesaian utang-utang dapat dibuat dengan jelas, baik menyangkut bentuk maupun jadwal waktunya. Kedua, agar Indonesia secepatnya dapat keluar dari krisis ekonomi ini, maka sangat diperlukan lembaga hukum yang dapat menyelesaikan utang-utang tersebut secara cepat, salah satunya diperlukan hukum kepailitan, disamping melakukan negosiasi untuk restrukturisasi dan penjadwalan utang-utang tersebut. Untuk itu, eksistensi hukum kepailitan sangat dibutuhkan sehingga perubahan terhadap undangundang kepailitan (Faillisements Verordening Stb. 1905 No. 217 jo. 1906 No. 348) perlu dilakukan melalui PERPU No. 1 Tahun 1998, tanggal 22 April 1998 yang selanjutnya telah menjadi Undang-Undang No. 4 Tahun 1998.

Dilihat dari perspektif ini, hukum kepailitan Indonesia yang dikonsep atas prakarsa IMF dan World Bank itu yang lebih berfungsi sebagai debt collection dibuat untuk menjamin pengembalian (assets recovery) utang-utang debitor bagi kreditor sebagai pemilik modal terutama kepentingan kreditor asing. Menurut Undang-Undang Kepailitan Indonesia, baik Undang-Undang No. 4 Tahun 1998 maupun Undang-Undang No. 37 Tahun 2004, pernyataan pailit haruslah diartikan sebagai sitaan umum yang bersifat conservatoir dan pihak yang dinyatakan pailit hilang penguasaannya atas harta bendanya. ${ }^{13}$ Pengertian pailit bukanlah suatu keadaan dimana debitor berada dalam kesulitan keuangan (financial distress) sehingga debitor tidak dapat (mampu) memenuhi seluruh kewajibannya kepada para kreditornya, atau pembayaran utang-utangnya. Selanjutnya, setelah selesai verifikasi utang, jika tidak ada perdamaian atau homoglasi perdamaian telah ditolak oleh pengadilan, maka demi hukum harta

${ }^{12}$ Ibid., hlm. 3.

${ }^{13}$ E. Suherman, Failissement (Kefailitan), Binacipta, cet. Pertama, Bandung, 1988, hlm. 5. 
pailit berada dalam keadaan tidak mampu membayar (insolvent). Kemudian asetaset debitor dilikuidasi untuk pelunasan utang-utang kepada para kreditornya. ${ }^{14}$

Jerry Hoff menyatakan, bahwa standar kepailitan yang dirumuskan Undang-Undang No. 4 Tahun 1998, yang sekarang diatur dalam Pasal 2 ayat (1) Undang-Undang No. 37 Tahun 2004, yang merupakan penyempurnaan dari Undang-Undang Kepailitan yang lama, yaitu Faillisement Verordening, yang memakai standar insolven untuk pernyataan pailit. Menurut Jerry Hoff,,15 Pasal 1 ayat (1) Undang-Undang No. 4 Tahun 1998 adalah merupakan standar dari keadaan tak mampu membayar utang. Standar ini lebih mudah dari pada standar yang dipergunakan dalam undang-undang yang lama (Faillissements Verordening Stbl. 1905-217 jo. 1906-348).16 Peraturan tentang Failisemen tidak memberikan definisi tentang failisemen dan hanya memberikan syarat untuk mengajuan permintaan failisemen, yaitu bahwa seseorang telah berhenti membayar. Berhenti membayar ialah kalau debitor sudah tidak mampu membayar atau tidak mau membayar, dan tidak usah benar benar telah berhenti sama sekali untuk membayar, tetapi apabila dia pada waktu diajukannya permohonan pailit berada dalam keadaan tidak dapat membayar utang tersebut (Putusan Pengadilan Tinggi Bandung No. 171/1973/Perd.PTB. tanggal 31 Juli 1973). ${ }^{17}$ Menurut Peter J.M. Declereq, tidak membayar tersebut tidak perlu diartikan apakah debitor benarbenar tidak mampu melakukan pembayaran utang atau karena tidak mau membayar utang. ${ }^{18}$

Keadaan tidak mampu membayar (insolvent) ini merupakan keadaan sebagaimana yang disebutkan dalam Pasal 168 , yang menentukan tidak mampu (insolvent)". Mengenai istilah insolven di sini, menurut Setiawan, keadaan tidak mampu ini, haruslah ditafsirkan "Pailit". Perubahan Undang-Undang Kepailitan yang tidak mengandung penilaian insolven diharapkan dapat dengan cepat

${ }^{14}$ Pasal 185 Undang-Undang No. 37 Tahun 2004.

15Jerry Hoff, Undang-Undang Kepailitan di Indonesia, Tatanusa, Jakarta , 2000, hlm.1.

${ }^{16}$ Pendapat inipun dibenarkan oleh Vesna Lazic pada saat seminar dan workshop bakrupty and arbitration:the effect of insolvency proceeding on the conduct of arbitration pada tanggal 8 dan 9 Maret 2004 di Hotel Brobudir, Jakarta, atas pertanyaan penulis berpendapat bahwa syarat ini lebih sempurna syarat kepailitan di negara lain.

${ }^{17}$ E. Suherman, Failissement (Kefailitan), Binacipta, cet. Pertama, Bandung, 1988, hlm. 5

18Peter J.M. Declereq, Netherlands Insolvency Law, The Netherlands Bankrupy Act and The most legal Important Legal Concept, T.M.C. Asser Press, The Haque, hlm. 63. A Bankruptyy petition has to state facts and circumtances that constitute prima facie evidence that the debtor has ceased to pay its debts. This considered to be the case if there are at least two creditors, one of who, has a claim is due and payable and which the debtor cannot pay, refuses to pay, or simply does not pay. 
menyelesaikan utang-utang swasta akibat krisis ekonomi dan mendapat pengaruh dari badan keuangan internasional. Pasal 2 Undang-Undang No. 37 Tahun $2004^{19}$ juga tidak membedakan kepailitan perseorangan (individual) dengan korporasi (corporate), perusahaan asuransi dan perbankan, dan tidak pula menyaratkan bahwa debitor tersebut dalam keadaan tidak mampu membayar (insolvent), debitor dapat dinyatakan pailit jika telah terpenuhi syarat yang ditentukan oleh undang-undang.

Menurut Sutan Remy Sjahdeini, keadaan berhenti membayar atau tidak membayar utang (not paying debts) ini haruslah merupakan keadaan yang objektif, yaitu karena keadaan keuangan debitor yang telah mengalami ketidakmampuan (telah dalam keadaan tidak mampu) membayar utang-utangnya. Dengan kata lain, debitor tidak boleh hanya sekedar tidak mau membayar utang-utangnya (not willing to repay his debts), tetapi keadaan objektif keuangannya memang telah dalam keadaan tidak mampu membayar utang-utangnya (unable to repay his debts). Keadaan tidak mampu ini (insolven) harus dapat ditentukan secara independen dan objektif dengan melakukan financial audit atau financial due diligence oleh kantor akuntan publik yang independence. Selanjutnya menurut Sutan Remy Sjahdeini, ${ }^{20}$ rumusan Pasal 1 ayat (1) Undang-Undang No. 4 Tahun 1998 tidak sejalan dengan asas hukum kepailitan yang diterima secara global. Undang-Undang Negeri Belanda misalnya, sampai sekarang masih tetap mempertahankan rumusan seperti rumusan Pasal 1 ayat (1) Fv tersebut di atas sekalipun undang-undang kepailitan negeri Belanda itu telah mengalami beberapa kali perubahan.

Menurut Ricardo Simanjuntak, ${ }^{21}$ tidak membayar utang (not paying debts) diasumsikan sebagai tidak mampu membayar (assumed not able to pay) yang mengakibatkan pengadilan menyatakan status pailit kepada debitor. Akan tetapi bila debitor masih mampu, berdasarkan Pasal 144 Undang-Undang No. 37 Tahun 2004, debitor dapat mengajukan usulan perdamaian, jika perdamaian tersebut disetujui oleh para kreditornya, debitor tersebut menjadi tidak pailit. Ketentuan

${ }^{19}$ Sebelumnya diatur dalam Pasal 1 ayat (1) jo. Pasal 6 ayat (3) Undang-Undang No. 4 Tahun 1998.

${ }^{20}$ Ibid., hlm. 53. 297.

${ }^{21}$ Ricardo Simanjuntak, Teknik Perancangan Kontrak Bisnis, Kontan Publishing, Jakarta, cet. II, 2011, hlm. 
ini sama dengan Hukum Kepailitan Belanda (Netherlands Insolvency Act). Ketentuan inipun sama dengan ketentuan hukum kepailitan Singapura dimana unsur ketidakmampuan debitor membayar utang-utangnya tidak harus dibuktikan, namun cukup dengan cara diasumsikan (assumption not able to pay). Artinya, Pengadilan Tinggi Singapura dapat menjatuhkan pailit berdasarkan debitor mempunyai utang yang telah jatuh tempo dan dapat ditagih, walaupun telah ditegur (statury demand) untuk melunasi utangnya, namun debitor tersebut tidak melunasinya. Dengan fakta ini diasumsikan tidak mampu membayar. ${ }^{22}$ Statutory demand menjadi ukuran pailit di Singapura. Menurut Kala Anandrajah et.al., sebagaimana yang dikutip Ricardo Simanjuntak, bahwa the statutory demand procedure is commonly resorted to as means of proving inability of the debtor to pay his debts for the purpose of presenting a creditor's petition. ${ }^{23}$

Menurut Ricardo Simanjuntak, ${ }^{24}$ tidak membayar utang (not paying debts) diasumsikan sebagai tidak mampu membayar (assumed not able to pay) yang mengakibatkan pengadilan menyatakan status pailit kepada debitor. Akan tetapi, bila debitor masih mampu, berdasarkan Pasal 144 Undang-Undang No. 37 Tahun 2004, debitor dapat mengajukan usulan perdamaian, jika perdamaian tersebut disetujui oleh para kreditornya, debitor tersebut menjadi tidak pailit. Ketentuan ini sama dengan Hukum Kepailitan Belanda (Netherlands Insolvency Act). Ketentuan inipun sama dengan ketentuan hukum kepailitan Singapura, dimana unsur ketidakmampuan debitor membayar utang-utangnya tidak harus dibuktikan, namun cukup dengan cara diasumsikan (assumption not able to pay). Artinya, Pengadilan Tinggi Singapura dapat menjatuhkan pailit berdasarkan debitor mempunyai utang yang telah jatuh tempo dan dapat ditagih, walaupun telah ditegur (statury demand) untuk melunasi utangnya, namun debitor tersebut tidak melunasinya. Dengan fakta ini diasumsikan tidak mampu membayar. ${ }^{25}$ Statutory demand menjadi ukuran pailit di Singapura. Menurut Kala Anandrajah et.al., sebagaimana yang dikutip Ricardo Simanjuntak, bahwa: the

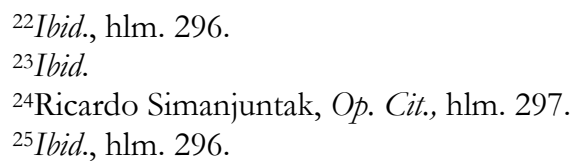


statutory demand procedure is commonly resorted to as means of proving inability of the debtor to pay his debts for the purpose of presenting a creditor's petition. 26

Dilihat dari konsep seperti ini, Undang-Undang Kepailitan telah mempailitkan perusahaan-peursahaan yang masih solvent dan prospektif, yang bertentangan dengan prinsip commercial exit from finacial distress sebagai prinsip utama dalam kepailitan korporasi.

Dalam Undang-Undang Kepailitan No. 37 Tahun 2004 disebutkan bahwa debitor yang dipailitkan itu adalah debitor yang tidak membayar utang. Dalam kenyataannya pengertian utang berkembang kepada pengertian di luar pengertian utang yang dimaksud dalam hukum kepailitan, debitor yang tidak memenuhi kewajibannya dalam suatu perjanjian dianggap sebagai utang yang harus dibayar oleh debitor. Utang telah ditafsirkan secara luas bukan saja utang yang timbul dari hubungan perjanjian utang piutang tetapi juga dalam hubungan perjanjian lainnya. Tafsiran utang ini memang muncul dari Undang-Undang No. 4 Tahun $1998 .{ }^{27}$

Walaupun Undang-Undang Kepailitan tidak secara tegas memberikan definisi tentang utang, berangkat dari rasio Pasal 1233, 1234, 1239, 1243 dan 1246 KUHPerdata, maka cukup jelas digambarkan bahwa utang tidak merupakan kewajiban dari perjanjian pinjam meminjam uang, akan tetapi juga berasal dari tindakan ingkar janji (wanprestasi) yang memberikan kewajiban kepada pihak yang dirugikan untuk mendapatkan ganti rugi atas akibat wanprestasi tersebut. Namun, kewenangan pengadilan niaga hanya akan muncul jika kewajiban tersebut dapat dibuktikan secara sumir. Perdebatan tentang definisi utang ini muncul dari perkara kepailitan Moderndland Reality dan Mahkamah Agung telah memutuskan definisi utang ini, namun masih ada putusan yang menyatakan utang hanya berasal dari kewajiban pinjam meminjam uang.

${ }^{26}$ Ibid.

${ }^{27}$ Jerry Hoff, Op. Cit., hlm. 18. 
Mahkamah Agung Membatalkan Putusan Pailit Perusahaan Solvable dan Viable (Prospektif) berdasarkan berbagai pertimbangan

Pertama, Perusahaan ini tidak membayar utang yang timbul dari tidak dipenuhinya suatu perjanjian pembangunan apartemen dan rumah susun. Perkara kepailitan terjadi dalam Drs. Husein Sani dan Johan. Kedua, permohonan pailit diajukan terhadap perusahaan asing yang juga sangat solvent yang diajukan oleh Kurator perusahaan yang telah dinyatakan pailit oleh pengadilan niaga karena perusahaan ini tidak membayar deviden kepada perusahaan yang telah dinyatakan pailit itu. Perkara kepailitan ini terjadi dalam PT Asuransi Manulife Indonesia(d/h. PT Asuransi Jiwa Dharmala Manulife) v. Paul Sukran, SH sebagai Kurator dari PT Dharma Sakti Sejahtera (PTDSS). PT Dharmala Sakti Sejahtera, Tbk. (dalam pailit) telah dinyatakan pailit. 28 Sejak PT Dharmala Sakti Sejahtera dinyatakan pailit, maka segala sesuatu yang menyangkut mengenai pengurusan harta kekayaan PT DSS (debitor pailit) sepenuhnya dilakukan oleh Kurator Selaku Kurator. ${ }^{29}$ Pemohon bertugas untuk melakukan pengurusan dan / atau pemberesan harta pailit serta berusaha mengumpulkan semua harta kekayaan yang dimiliki oleh PT DSS selaku debitor pailit, termasuk juga dalam upaya memaksimalkan budel pailit itu, untuk selanjutnya dibagikan kepada para kreditornya, sehingga para kreditor dapat memperoleh bagian yang maksimal dari pembagian budel pailit sebagaimana diamanatkan dalam ketentuan UndangUndang No. 4 Tahun 1998, termasuk pembagian untuk Negara Republik Indonesia selaku kreditor yang dalam hal ini diwakili oleh Badan Penyehatan Perbankan Nasional (BPPN).

Ketiga, permohonan pailit diajukan terhadap perusahaan asing yang juga sangat solvent oleh konsultan jasa asuransi karena perusahaan ini tidak membayar bonus kepada pemohon yang telah memenuhi target penjualan produk asuransi. Perkara kepailitan ini terjadi terhadap PT Prudential Life telah dimohonkan pailit oleh Mr. Lee Boo Siong, konsultan Jasa Asuransi dan keagenan.

${ }^{28}$ Lihat Putusan Pengadilan Niaga pada Pengadilan Negeri Jakarta Pusat No. 03/PKPU/ 2000/PN.Niaga.Jkt.Pst.jo. No. 10/PAILIT/2000/PN.Niaga.Jkt.Pst., tanggal 6 Juni 2000,

${ }^{29}$ Lihat Penetapan Pengadilan Niaga pada Pengadilan Negeri Jakarta Pusat No. 10/PAILIT/2000/PN.Niaga.Jkt.Pst., jo. No. 03/PKPU/2000/PN.Niaga.Jkt.Pst., tanggal 21 Desember 2000. 
Keempat, perusahaan yang menjalankan bisnisnya di bidang penyiaran televisi. Perusahaan ini juga masih solvent. Perusahaan ini dinyatakan pailit karena tidak melakukan pembayaran/pelunasan atas Subordinated Bonds. Kepailitan ini terjadi dalam PT Cipta Televisi Pendidikan Indonesia v. Crown Capital Global Limited di Pengadilan Niaga pada Pengadilan Negeri Jakarta Pusat.

Kelima, perusahaan yang bergerak dalam bisnis telekomunikasi selular dan merupakan perusahaan yang sangat strategis dalam bisnis telekomunikasi. Pailitnya perusahaan ini menarik perhatian banyak pihak termasuk pihak pemerintah karena perusahaan ini adalah satu-satunya BUMN milik pemerintah yang bergerak dalam industri strategis telekomunikasi, kondisi perusahaan ini juga sangat solvent. Perusahaan ini dipailitkan oleh Pengadilan Niaga Jakarta Pusat karena tidak membayar Purchase Order yang menimbulkan utang yang telah jatuh tempo. Kepailitan ini terjadi dalam PT Telekomunikasi Selular v.PT Prima Jaya Informatika. ${ }^{30}$

Keenam, perusahaan negara yang bergerak dalam pembuatan pesawat udara telah dinyatakan pailit oleh pengadilan niaga Jakarta Pusat atas permohonan pailit yang diajukan oleh para karyawannya karena tidak membayar gaji karyawannya. Perusahaan ini dalam keadaan solvent dan tempat bekerja banyak karyawan. Kepailitan ini terjadi dalam PT Dirgantara Indonesia (Persero) $v$. Heriyono, dkk. Para pemohon itu adalah 1. Heryono, bertempat tinggal di Fokker Raya No. 39 RT.02/03, Cimahi, 2. Nugroho, bertempat tinggal di Jalan Taruna No. 7RT.05/02, Ujung Berung 3. Sayudi, bertempat tinggal di Perum Bukit Berlian C15RT.02/25, Kartamulya Padalarang.

Pailitnya perusahaan yang solvent dan prospektif itu di pengadilan niaga bertentangan dengan konsep dan prinsip-prinsip hukum kepailitan korporasi, terutama prinsip commercial exit from financial distress dan konsep likuidasi. Mahkamah Agung telah membatalkan putusan-putusan pailit tersebut berdasarkan berbagai pertimbangan, diantaranya permohonan pailit tersebut tidak dapat dibuktikan secar sederhana.

\footnotetext{
${ }^{30}$ Perkara pailitnya PT Telkomsel ini menjadi perhatian dan termasuk yang diawasi UKP4 suatu lembaga yang berada di bawah Presiden.
} 


\section{Kreditor Memilih PKPU untuk Menagih Utang Korporasi Pailit}

Ada perkembangan baru yang terjadi di Indonesia, PKPU diajukan oleh kreditor. ${ }^{31}$ Jika PKPU ini diajukan dengan iktikad baik untuk menghindari pailit, penggunaan PKPU ini mengikuti perkembangan baru dalam kepailitan korporasi. Kreditor-kreditor ini lebih memilih PKPU dari pada mengajukan permohonan pailit. Di sini, ada berbagai motif kreditor lebih memilih PKPU dari pada kepailitan, diantaranya untuk menghindari iktikad buruk dari kreditor dalam menggunakan lembaga kepailitan, endings atau penyelesaian akhir utang-utang melalui proses kepailitan kepailitan itu sendiri tidak menguntungkan bagi kreditor, terutama pada saat likuidasi atau pemberesan budel pailit. Dalam hal ini, mungkin jalan yang lebih baik adalah menggunakan upaya hukum PKPU.

Adanya kecenderungan penggunaan PKPU menjadi pilihan oleh para kreditor karena debitor yang solvent tidak membayar utangnya juga dapat dihubungkan dengan asas kelangsungan usaha yang dianut Undang-Undang No. 37 Tahun 2004 untuk lebih mengedepankan PKPU yang mempunyai roh perdamaian dan pailit merupakan ultimum remidium apabila usaha damai tidak dapat dilaksanakan. Sebaliknya, PKPU jika digunakan dengan iktikad tidak baik, PKPU dapat menjadi instrumen untuk mempercepat dipailitkannya debitor. Oleh karena itu, PKPU belum seutuhnya menjadi instrumen untuk menerapkan corporate rescue sebagai konsep dalam penyelesaian utang-utang korporasi. Sedangkan asas kelangsungan usaha sama dengan corporate rescue dan berbeda dengan PKPU, tetapi asas ini tidak menjadi norma hukum dalam rumusan pasalpasal Undang-Undang No. 37 Tahun 2004.

Dipilihnya PKPU ini oleh Kreditor dapat dilhat dalam PT Bank Central Asia, Tbkv. PT Arpeni Pratama Ocean Line, Tbk. PT Bank Central Asia, Tbk suatu perseroan terbatas yang didirikan menurut hukum negara Republik Indonesia, yang berkedudukan di Jakarta mengajukan permohonan PKPU terhadap PT Arpeni Pratama Ocean Line, Tbk.

${ }^{31}$ Lihat Pasal 222 (3) Undang-Undang No. 37 Tahun 2004 menyatakan: Kreditor dapat mengajukan PKPU terhadap debitor, ketentuan ini sama dengan Chapter 11 US Bankrupty Code, ketentuan ini berlainan dengan Undang-Undang No. 4 Tahun 1998, yang dapat mengajukan PKPU hanya Debitor. 
Kreditor memilih PKPU dari pada mengajukan permohonan pailit kepada perusahaan yang tidak membayar utang. Permohonan PKPU ini terjadi dalam PT Bank Mandiri v. PT Berlian Laju Tanker, Tbk. ${ }^{22}$ PT Bank Mandiri mengajukan permohonan PKPU terhadap PT Berlian Laju Tanker, Tbk.

Selanjutnya, dua dari perkara PKPU itu, permohonan PKPU dinyatakan tidak dapat diterima, yaitu dalam PT Putra Sejati Indomakmur v. PT Pertamina Hulu Energi Raja Tempirai dan PT Golden Spike Energy Indonesiadengan pertimbangan sampai dengan permohonan a quo, JOB Pertamina-Golden Spike Indonesia Ltd qq Para Termohon belum menyelesaikan kewajibannya sebesar USD 1.215.918 (satu juta dua ratus lima belas ribu sembilan ratus delapan belas koma tujuh puluh delapan sen dollar Amerika Serikat), hal ini membuktikan bahwa utang JOB Pertamina-Golden Spike Indonesia Ltd qq Para Termohon kepada Pemohon telah jatuh tempo dan dapat ditagih dan disamping pihak JOB Pertamina-Golden Spike Indonesia Ltd qq Para Termohon memiliki utang yang sudah jatuh tempo dan dapat ditagih kepada Pemohon sebagaimana disebutkan di atas, Pihak JOB Pertamina-Golden Spike Indonesia Ltd qq Para Termohon juga memiliki utang kepada para Kreditor lain, diantaranya: PT Lemtek Konsultan Indonesia dan PT Global Pasific Energy.

\section{Mahkamah Agung Melakukan Terobosan Hukum (Legal Breakthrough) dengan menerapkan Asas Kelangsungan Usaha terhadap Perusahaan yang Masih Solvable dan Viable (Prospektif)}

Mahkamah Agung dalam putusan peninjauan kembali (PK) dalam PT Citra Jimbaran Indah Hotel v. Ssangyong Engenereing \& Construction Co. Ltd. telah melakukan terobosan hukum (legal breakthrough) terhadap Undang-Undang No. 4 Tahun 1998. Terobosan hukum adalah merupakan Judge made law,33 atau penemuan hukum yang biasa dilakukan oleh hakim dalam penerapan hukum.

32Putusan PKPU Pengadilan Niaga pada Pengadilan Negeri Jakarta Pusat No. 27/PKPU/2012/PN.Niaga.Jkt.Pst Tanggal 3 Juli 2012.

33 Malcolm D.H. Smith and Kevin s. Pose, Legal proces, Commentatory and Materials, CBC Casebodes, Sydney, fifth edition, 1998, hlm 562. There is not doubt that historically judges did make law, at least in sense formulating it. Even now when they are against innovation, they have never formally abrogated theirs power: their attitude is : we could if we would but we think it better not. Most commentators therefore start from the assumption that English judges are law maker and that real question is weather they should not make law with more verve than they do. 
Undang-undang lebih ditafsirkan tidak secara tekstual tetapi lebih kepada keadilan dan kemanfaatan. Walaupun judge made law ini biasa dilakukan dalam tradisi common law, namun di Indonesia Mahkamah Agung dapat pula melakukan judge made law ini.

Terobosan hukum dalam perkara kepailitan ini dilakukan untuk membatalkan putusan pailit terhadap perusahaan yang solvable dan masih mempunyai prospektif. Sangyong Engineering \& Construction Co. Ltd. mengajukan permohonan pailit terhadap PT Citra Jimbaran Indah Hotel.

Adapun yang menjadi pertimbangan hukum dalam pemeriksaan PK bahwa Majelis Hakim kasasi telah melakukan kesalahan berat karena telah mengabaikan bunyi penjelasan umum dari makna yang terkandung dalam PERPU No. 1 Tahun 1989 yang telah ditetapkan menjadi Undang-undang No. 4 Tahun 1998 dimana secara esensial ditentukan bahwa kepailitan penerapannya harus dilakukan/diselesaikan secara adil dalam arti memperhatikan kepentingan perusahaan sebagai debitor atau kepentingan kreditor secara seimbang. Potensi dan prospek dari usaha debitor harus pula dipertimbangkan pula secara baik. Jika Debitor masih mempunyai potensi dan prospek, sehingga merupakan tunastunas yang masih dapat berkembang seharusnya masih diberi kesempatan untuk hidup dan berkembang. Oleh karena itu penjatuhan pailit merupakan ultimum remidium". Debitor pailit memiliki usaha hotel berbintang lima bernama Hotel Bali Intercontinenatal resort berlokasi di kawasan Wisata Pulau Bali. Kawasan itu selama terjadi krisis ekonomi dan keuangan relatif tidak terpengaruh, justru sebaliknya telah menuai keuntungan-keuntungan/advantages dan benefits dari kurs nilai tukar antara rupiah dan dollar Amerika Serikat. Potensi dan prospek itu telah dimiliki oleh debitor, hal ini terbukti dengan adanya keberatan dari para kreditor lainnya yaitu dari Bank Negara Indonesia dan Bank Bumi Daya yang merasa kepentingannya dirugikan jika debitor pailit dijatuhkan pailit.

Piutang yang dimiliki oleh PT Bank Bumi Daya dan PT Bank Negara Indonesia adalah kurang lebih Rp. 610.000.000.000,- (Enam ratus sepuluh milyar). Piutang para kreditor lainnnya itu di atas merupakan suatu jumlah yang jauh lebih besar jika dibandingkan dengan piutang Pemohon pailit yang berjumlah US $\$ 5,979,863.06$ (lima juta sembilan ratus tujuh puluh sembilan ribu delapan ratus 
enam puluh tiga dollar Amerika dan enam sen). Dengan adanya keberatan dari bank itu di atas Debitor/Termohon pailit telah diadakan restrukturisasi menunjukan bahwa usaha Debitor masih mempunyai potensi dan prospek untuk berkembang dan selanjutnya dapat memenuhi kewajibannya kepada seluruh Kreditor di kemudian hari dan oleh karena itu Debitor/Termohon pailit bukan merupakan a Debitor is hopelessly in debt. Berdasarkan construction contract antara Pemohon pailit dan Debitor pailit ternyata kewajiban debitor pailit semula adalah sebesar Rp. US \$ 75,558,774.50 (tujuh puluh lima juta lima ratus lima puluh delapan ribu tujuh puluh tujuh empat dollar dan lima puluh sen) sedangkan sisa utang sekarang US $\$ 5,979,863.06$ (lima juta sembilan ratus tujuh puluh sembilan ribu delapan ratus enam puluh tiga dollar dan enam sen) menunjukkan debitor telah memenuhi sebagian besar kewajibannya dan selayaknya diberi kesempatan melunasi sisa kewajibannya secara wajar. Dalam hal ini walaupun terbukti telah mempunyai utang yang telah jatuh tempo dapat ditagih, tetapi debitor masih mempunyai keyakinan untuk memberdayakan kembali usahanya debitor dapat memohon PKPU ${ }^{34}$ dan berdasarkan Pasal 217 Undang-Undang Kepailitan apabila permohonan pailit dan permohonan PKPU diajukan pada saat yang bersamaan, maka permohonan PKPU harus diputuskan terlebih dahulu, hal inilah yang membedakannya dengan chapter 11 US bankruptcy code dalam rerstrukturisasi utang dan organisasi itu.

Perlunya lembaga PKPU dan Chapter 11 dalam sistem hukum kepailitan, sejalan dengan pendapat beberapa penulis yang prinsipnya meragukan manfaat dari hukum kepailitan dalam mengatasi masalah seputar hal kreditor-debitor dan masalah insolvensi debitor. Upaya-upaya mengatasi atau menolong perusahaan dalam kesulitan keuangan juga dapat ditengarai dari diterbitkannya principles for multy-bank workouts atau statement of principles for a global approach to multi-creditor workouts, pada Tahun 2000 yang disusun oleh INSOL International yang dinaungi oleh INSOL Lender Group. Pada dasarnya ke-7 prinsip yang dituangkan dalam paduan itu adalah hasil pengamatan yang telah berlangsung selama kurang lebih 30 tahunan, yang akhirnya mengantarkan para kreditor dan lembaga keuangan internasional yang tergabung dalam INSOL itu, pada suatu keyakinan bahwa

${ }^{34}$ Ricardo Simanjuntak, Op. Cit., hlm. 12. 
sebagai kreditor mereka : ...can achieve better returns through supporting an orderly and expeditious rescue or workout of a business in financial difficulty than by forcing it into formal insolvency. 35

Sebagaimana yang telah diuraikan, hukum kepailitan korporasi (perseroan) Indonesia tidak mengenal konsep seperti yang diatur dalam chapter 11 US bankruptcy code, karena, perusahaan yang dinyatakan pailit atau yang sedang dimohonkan pailit dapat mengajukan permohonan PKPU sebagai upaya hukum untuk melawan permohonan pailit yang diajukan oleh Kreditor, jika Debitor itu memang dalam keadaan solven. Adanya prospek yang baik, adanya iktikad baik serta sikap kooperatif dari Debitor tidak dapat dijadikan pertimbangan untuk tidak mengabulkan permohonan pailit oleh hakim niaga. Namun dalam putusan kembali (PK), Mahkamah Agung dalam putusan No. 024/PK/N1999 dalam PT Citra Jimbaran Indah Hotel v.Ssangyong Engineering \& Construction Co. Ltd telah mengabulkan permohonan peninjauan kembali dengan pertimbangan bahwa potensi dan prospek dari usaha Debitor harus pula dipertimbangkan pula secara baik. Jika Debitor masih mempunyai potensi dan prospek, sehingga merupakan tunas-tunas yang masih dapat berkembang seharusnya masih diberi kesempatan untuk hidup dan berkembang. Penjatuhan putusan pailit merupakan ultimum remidium. Di samping itu, terhadap Debitor/Termohon pailit telah diadakan restrukturisasi menunjukkan bahwa usaha Debitor masih mempunyai potensi dan prospek untuk berkembang dan selanjutnya dapat memenuhi kewajibannya kepada seluruh Kreditor di kemudian hari dan oleh karena itu Debitor/Termohon pailit bukan merupakan a Debitor is hopelessly in debt .

\section{Mahkamah Agung Menggunakan Syarat Pembuktian Sederhana sebagai Clausule Escape untuk Tidak Mempailitkan Perusahaan Solvable dan Viable (Prospektif)}

Sebagai bentuk lain tidak dipailitkannya perusahaan yang masih solvable dan viable, Mahkamah Agung membatalkan putusan pengadilan niaga dengan dasar permohonan pailit itu tidak dapat dibuktikan secara sederhana dan sengketa itu terlebih dahulu harus diselesaikan melalui pengadilan perdata. Di 2000,hlm.4. 
sini Mahkamah Agung menggunakan syarat pembuktian sederhana sebagai clausule escape untuk melindungi dampak langsung dari suatu permohonan pailit terhadap perusahaan-perusahan yang masih solvable dan viable. Peruasahaanperusahaan ini sebenarnya juga tidak layak untuk dinyatakan pailit.

Dalam yurisprudensi Nederland, ${ }^{36}$ disebutkan bahwa penagih utang yang mohon pailit cukup menunjukkan secara sumir dasar-dasar gugatannya bahwa persyaratan itu telah ada dan terpenuhi. Bahkan putusan-putusan Hoge Raad ${ }^{37}$ lebih lanjut menyatakan bahwa dalam permohonan pailit itu belum perlu disebutkan jumlah utang yang pasti (eksak). Kepastian ini nanti baru pasti jumlah utangnya dalam tahap rapat verifikasi setelah putusan pailit dijatuhkan. Dengan demikian, cukuplah secara sumir dapat dinyatakan bahwa fakta-fakta atau keadaan-keadaan dimana si pengutang itu memang mempunyai utang dan bahwa ia telah berhenti membayar kembali.

Pengertian secara sumir atau secara sederhana haruslah dilihat secara kasuistis dalam setiap perkara, apakah memang secara mudah dapat dibuktikan terpenuhinya syarat-syarat untuk mengajukan permohonan kepailitan. Karenanya kemudahan atau kesederhanaan pembuktian ini menjadi kretiria untuk menilai apakah persyaratan-persyaratan kepailitan telah terpenuhi, sehingga proses pemeriksaan perkara dapat diputuskan secara cepat.

Adanya banyak hal yang dapat menyebabkan pemeriksaan perkara dan pembuktiannya tidak dapat dilakukan secara mudah, sederhana dan cepat. Salah satu hal diantaranya adalah apabila terdapat perjanjian yang timbal balik, dimana kedua belah pihak (kreditor dan debitor) masing-masing mempunyai hak dan kewajiban yang timbal balik dan harus dipenuhi, misalnya jual-beli. Penjual berkewajiban untuk menyerahkan barangnya dan berhak atas pembayaran harga barangnya, tetapi sebaliknya juga pembeli berkewajiban untuk membayar harga barang dan berhak atas penyerahan barang yang bersangkutan. Dalam hal ini, dapat terjadi bahwa pembeli melakukan gugatan terhadap penjual untuk menyerahkan barang, tetapi kemudian pihak penjual mengajukan eksepsi bahwa gugatan itu belum waktunya untuk diajukan atau tidak dapat diajukan oleh

36Putusan Hoge Raad tanggal 2O Mei 1998, NJ.1989, 676.

${ }^{37} I$ bid, tanggal 15 November 1985, NJ.1986, 154 dan Putusan tanggal 18 April 1986, NJ.1986, 530. 
pembeli, sebab pembeli itu sendiri justru belum memenuhi prestasinya, yaitu harus membayar harga barang. Di sini pihak penjual itumengajukan exeptio non adimppleti contractus. Kedua belah pihak akan mendapat kesempatan yang sama untuk didengar dan saling melakukan pembuktian, atas dasar prinsip Audi et alteram partem. Dalam proses pembuktian demikian akan dapat terjadi berbagai upaya hukum, misalnya gugatan rekonvensi, intervensi masuknya pihak ke-III, penyitaan, dan sebagainya sehingga proses pembuktiannya dimungkinkan akan dapat komplek.

Atas dasar hipotesa demikian, maka apabila dalam suatu proses permohonan pailit, ternyata pihak termohon mengajukan exeptio non adimpleti contractus sehingga eksistensi adanya utang itu sendiri masih dapat diperdebatkan (bukan sekedar tentang besarnya utang), dan pengadilan dapat menerima alasan itu, maka fakta dan keadaan atau eksistensi utang itu tidak dapat dibuktikan secara mudah dan sederhana (sumir). Lain halnya, apabila yang diperdebatkan itu hanyalah tentang jumlah besarnya utang, sedangkan adanya atau eksistensi, utangnya itu sendiri sudah jelas terbukti dan tidak dipermasalahkan, maka dalam hal demikian tidak terbuka kemungkinan untuk mengajukan exceptio non adimpleti contractus.

Besar-kecilnya jumlah utang itu akan dapat ditentukan dalam rapat verifikasi atau rapat pencocokan utang, sesudah debitor dinyatakan pailit dalam putusan hakim. ${ }^{38}$ Apabila jumlah utang, menurut majelis kasasi perbedaan jumlah utang tidak dapat diselesaikan lewat verifikasi dan harus diselesaikan melalui pengadilan negeri (Pengadilan perdata), tetapi sebaliknya dalam PT Alcarindo Prima (AP) v. Pulung Copper Works, I.TD, majelis kasasi menyatakan bahwa perbedaan utang itu dapat diselesaikan dalam rapat verifikasi.

Dalam beberapa perkara suatu utang dianggap tidak dapat dibuktikan secara sederhana karena majelis hakim sulit untuk memposisikan para pihak sebagai kreditor dan debitor, misalnya bila Termohon pailit mengajukan suatu exeptio non adimpleti contractus, seperti dalam Waskita Karya (WK) v. PT Mustika Princess Hotel (MPH).Karena terlihat adanya indikasi bahwa Pemohon dan

38 Undang-Undang No. 4 Tahun 1998, Pasal 104 dan seterusnya. 
Termohon Pailit masing-masing berkedudukan sebagai debitor dan kreditor, maka utang tidak lagi dapat dibuktikan secara sederhana.

Untuk membuktikan adanya Kreditor lain, dalam prakteknya, tidak selalu ditandai dengan hadirnya kreditor lain itu dipersidangan, tetapi juga adanya piutang yang dimiliki oleh kreditor lain kepada Termohon pailit, seperti dalam Royal Bank of Canada v. PT Ometraco Corporation, RBC dianggap tidak dapat membuktikan adanya kreditor lain karena bukti yang diajukan hanya berupa facility agreement dan salinan putusan Mahkamah Agung.

Dalam Tim Likuidasi PT Bank Astria Raya v. PT Multi Citi Agung, surat Bank Indonesia yang membuktikan adanya kreditor lain, majelis hakim kasasi berpendapat cukup sederhana untuk membuktikan adanya kreditor lain. Contoh lain, dalam Drayton Kiln, ltd (DK) v. PT Dekormas Mulia Industries, hakim berpendapat bahwa kreditor lain yang masih dalam penjadwalan dapat merupakan bukti adanya kreditor lain. Kemungkinan lain, dalam PT Bank Artha et.al v. Cheng Basuki adanya tanggapan dari kreditor lain di persidangan merupakan bukti adanya kreditor lain. Tetapi sebaliknya, dalam PT Nikko Securities Indonesia (NSI) v. PT Pujiadi Pretice Limited, Tbk, sangkalan kreditor lain, juga dapat membuktikan tidak adanya kreditor lain. Menurut penulis, persyaratan dapat dibuktikan secara sederhana ini dapat pula disalahgunakan, apabila perkaranya rumit dan hakim yang menangani perkara yang bersangkutan tidak menguasai hukum mengenai apa yang disengketakan, hakim yang bersangkutan akan cenderung menyatakan permohonan pailit tidak dapat diterima dengan alasan pembuktiannya tidak sederhana. Dengan demikian, syarat ini telah digunakan oleh Mahkamah Agung RI sebagai clausule escape untuk membatalkan putusan pailit yang tidak tepat.

Sikap Mahkamah Agung RI terhadap pailitnya perusahaan-perusahaan solvent dan viable itu dimana Mahkamah Agung membatalkan putusan-putusan pengadilan niaga dengan berbagai pertimbangan, termasuk putusan yang menerapkan asas kelangsungan usaha, yang berasal dari konsep corporate rescue tidak menjadi kaedah hukum yang mengikat bagi pengadilan niaga karena sistem hukum Indonesia tidak menganut sistem precedent, dimana putusan Mahkamah Agung menjadi putusan yang mengikat (binding) bagi pengadilan yang di 
bawahnya, sehingga sampai sekarang pun pengadilan niaga dapat mempailitkan perusahaan yang solvable dan viable, tanpa merasa ada kejanggalan di sana. Kondisi ini dapat dibenarkan dalam kaca mata paradigma legisme hukum, atau hukum modern, namun tidak dapat dibenarkan dari kaca mata paradigma post modern.

\section{Penutup}

Berdasarkan hasil penelitian yang telah diuraikan, dapat disampaikan kesimpulan sebagai berikut. Pertama, pailitnya perusahaan-perusahaan yang masih solvable dan viable (prospektif) di Pengadilan Niaga ada hubungannya dengan konsep yang diterapkan di dalam Undang-Undang Kepailitan. UndangUndang Kepailitan itu berada dalam teori-teori yang dikonstruksikan dengan konsep likuidasi untuk penyelesaian pembayaran utang-utang tanpa membedakan debitor korporasi atau perseorangan. Dilihat dari perspektif pergeseran paradigma (shifting of paradigm), konsep ini sudah tidak dipakai lagi dalam kepailitan korporasi. Dalam kepailitan korporasi yang diterapkan adalah konsep corporate rescue.

Kedua, pailitnya perusahaan-perusahaan solvent di Pengadilan Niaga, selanjutnya disikapi oleh Mahmakah Agung dengan membatalkan putusan hakim Pengadilan Niaga berdasarkan berbagai pertimbangan. Di antaranya adalah perusahaan tersebut masih prospektif dan masih harus diberi kesempatan untuk melanjutkan bisnis perusahaannya dan permohonan pailit tersebut tidak dapat dibuktikan secara sederhana. Salah satu putusan Mahkamah Agung yang dapat dijadikan kaedah hukum adalah putusan No. 024 PK/N/1999 dalam PT Citra Jimbaran Indah Hotel v. Sangyong Engineering \& Construction Co. Ltd. Mahkamah Agung RI telah mengabulkan permohonan peninjauan kembali dalam perkara kepailitan ini karena perusahaan debitor masih dalam keadaan prospektif (viable), perusahaan debitor masih perlu diberikan kesempatannya untuk menjalankan bisnisnya, sehingga debitor masih berpotensi untuk dapat melunasi utang-utangnya. Kepailitan dengan cara melikuidasi perusahaan debitor dipandang tidak ada manfaatnya. Putusan peninjauan kembali Mahkamah 
Agung menerapkan asas kelangsungan usaha. Putusan ini dianggap tidak lazim dan merupakan terobosan hukum (legal breakthrough) terhadap teks UndangUndang No. 4 Tahun 1998. Namun putusan-putusan Mahkamah Agung ini tidak menjadi kaedah hukum bagi hakim Pengadilan Niaga yang memutus perkara permohonan pailit setelah itu, sehingga pailitnya perusahaan-perusahaan solvable dan viable ini tetap berlanjut. Sementara itu, ada kecenderungan baru yang memperlihatkan bahwa kreditor memilih permohonan PKPU terhadap perusahaan yang tidak membayar utang, yang seharusnya disikapi dengan hatihati, ketika PKPU ini juga digunakan dengan iktikad tidak baik atau buruk (bad faith). Karena, PKPU dapat menjadi jalan pintas debitor perusahaan dipailitkan tanpa adanya upaya hukum lainnya.

Ketiga, adanya kelemahan penguasaan konsep dan prinsip hukum kepailitan korporasi sebagai hal yang mendasar dari hakim yang menangani perkara-perkara kepailitan, sehingga tidak dapat keluar dari bunyi teks undangundang. Undang-Undang hanya diterapkan secara positivistic legal thinking, sehingga pailitnya perusahaan solvable tersebut juga tidak dapat dilepaskan dari persoalan ini. Undang-Undang Kepailitan ini tidak dapat lagi diterapkan dalam kepailitan korporasi. Undang-Undang ini perlu untuk direkonstruksi dengan cara: (i) Memisahkan kepailitan korporasi dari kepailitan perseorangan. Pemisahan kepailitan perseorangan ini perlu dilakukan dalam suatu sistem hukum kepailitan karena kedua bentuk kepailitan itu membawa dampak yang berbeda. Kepailitan korporasi akan membawa dampak yang lebih luas daripada kepailitan perseorangan. (ii) Insolvent menjadi ukuran untuk kepailitan korporasi. Standar kepailitan korporasi adalah adanya ketidakmampuan untuk membayar utang (unable to pay debts) yang disebabkan adanya krisis keuangan yang dialami oleh perusahan tersebut. Penilaian terhadap ketidakmampuan ini (insolvency test) dapat berupa cash flow test dan balance sheet test dari perusahaan yang bersangkutan. (iii) Menerapkan asas kelangsungan usaha yang merupakan konsep corporate rescue dalam norma Undang-Undang Kepailitan Korporasi atau Undang-Undang Perseroan Terbatas. (iv) Adanya aturan yang lebih tegas terhadap pencabutan kepailitan perusahaan yang sudah tidak lagi mempunyai aset-asetnya. Salah satu dari tujuan kepailitan adalah juga to provide effective 
realease from the financial liabilities and obligation of the unsolvent. Di Belanda, terhadap debitor yang sudah tidak asetnya lagi, setelah lima tahun dapat mengajukan permohonan untuk diberi kesempatan untuk berusaha kembali untuk memulihkan kecakapan dalam bertindak.

\section{Daftar Pustaka}

D.H. Smith, Malcolm and Kevin s. Pose, Legal proces, Commentatory and Materials, CBC Casebodes, Sydney, fifth edition, 1998.

Hoff, Jerry, Undang-Undang Kepailitan di Indonesia, Tatanusa, Jakarta, 2000.

Hoff, Jerry, UU Kepailitan di Indonesia, (Indonesia Bankruptcy Law), Terjemahan Kartini Mulyadi, Jakarta, 2000.

J.M. Declereq, Peter, Netherlands Insolvency Law, The Netherlands Bankrupcy Act and The most legal Important Legal Concept, T.M.C. Asser Press, The Haque.

Lazic, Vesna, pada saat seminar dan workshop bakruptcy and arbitration:the effect of insolvency proceeding on the conduct of arbitration pada tanggal 8 dan 9 Maret 2004 di Hotel Borobudur, Jakarta.

Mahkamah Agung, Kumpulan Putusan Perkara Kepailitan dalam Putusan Kasasi dan PK , 2000.

Remy Sjahdeini, Sutan, "Recent Development on Indonesia's Bankruptcy Law," Paper yang disampaikan pada The General Meeting of ALA on 26 - 28 May 2003 di Shangri-La Hotel, Singapore.

Simanjuntak, Ricardo, Teknik Perancangan Kontrak Bisnis, Kontan Publishing, Jakarta, cet. II, 2011.

Simanjuntak, Ricardo, Hukum Kontrak, Tehnik Perancangan Kontrak Bisnis,Kontan Publishing, Jakarta, 2006.

Statement of Principles for A Global Approach to Multy-Creditor Workouts-INSOL International-London, 2000.

Subhan, Hadi, Hukum Kepailitan, Prinsip,Norma dan Praktek di Peradilan, Kencana Prenada Media Group, Jakarta, 2008.

Suherman, E., Failissement (Kefailitan), Binacipta, cet. Pertama, Bandung, 1988.

Tomansic, Roman, "Creditor Participation in Insolvency Proceedings,"Work Paper, OECD, Paris, 2006.

Putusan Pengadilan Niaga pada Pengadilan Negeri Jakarta Pusat No. 03/PKPU/ 2000/PN.Niaga.Jkt.Pst.jo. No. 10/PAILIT/2000/PN.Niaga.Jkt.Pst., tanggal 6 Juni 2000, 
Penetapan Pengadilan Niaga pada Pengadilan Negeri Jakarta Pusat No. 10/PAILIT/2000/PN.Niaga.Jkt.Pst., jo. No. 03/PKPU/2000/PN.Niaga.Jkt. Pst., tanggal 21 Desember 2000.

Putusan PKPU Pengadilan Niaga pada Pengadilan Negeri Jakarta Pusat No. 27/PKPU/2012/PN.Niaga.Jkt.Pst Tanggal 3 Juli 2012.

Undang-Undang No. 37 Tahun 2004

Undang-Undang No. 4 Tahun 1998

file://C:/Program\%20File/DatabaseKepailitan/Resume.htm, Akses 31 Maret 2014. 